\title{
Laughing at leaders (American politicians especially)
}

Thomas E. Cronin

McHugh Professor of American Institutions and Leadership at Colorado College, Colorado College, Colorado Springs, CO, USA

People everywhere laugh at their political leaders, not only to vent their outrage at ineptness or corruption in government, but also to express a basic instinct for independence from authority. The way we laugh at our political leaders reveals both our humanness and our conflicting expectations for leadership. This essay examines how and why citizens laugh at their leaders (especially American politicians), and what this tells us about the challenges of political leadership.

The functions of political humor are analysed. The role of snark, or snide sarcasm, is described as a parallel culture to the life of politics and leadership. Rich political humor should leave us laughing, curious, and perhaps unsettled, yet not giving up on politics.

Keywords: leadership, leaders, humor, jokes, satire, politics, politicians, laughter, distrust, cynicism

When it comes to the powerful and to political leaders, wrote American humorist Mark Twain, 'the human race has one really effective weapon - laughter... Against the assault of laughter nothing can stand.'

Twain was only partly right. There are other weapons against those in authoritative positions, for example, aggression, revolution, war, or escape. Sadly, too, laughter is usually not enough to defeat toxic leaders.

This essay discusses humor and political leadership. Why do we laugh at politicians? How do we laugh at them, and what is the role of partisan humor, of satire, personal ridicule, and 'snark'? When does political humor cease to be a laughing matter?

\section{WHY WE LAUGH AT LEADERS}

Every society laughs at its leaders, especially when they get 'too big for their boots or hats.' Lampooning the high, mighty, and humor-challenged has been an age-old pastime. Greek comic poets like Aristophanes ridiculed Athenian political leaders to the delight of Athenian playgoers. ' 'Ingratitude towards their great men,' Plutarch approvingly noted, 'is the mark of a strong people.' Even the Bible says there is a time to laugh. And we all fear that 'where there be no mirth, there be madness.'

As long as there have been leaders who disappoint, there have been jokesters, satirists, and cartoonists who cleverly afflict the pompous and try to comfort and entertain the rest of us. 'A sense of humor is a great cure,' writes Israeli novelist Amos Oz (2006, pp. 64-65). 'I have never once in my life seen a fanatic with a sense of humor, nor have I seen a person with a sense of humor become a fanatic.'

1. See Zumbrunnen (2012). 
Political satire exposes or pokes fun at political customs and institutions and those involved in politics. If people get angry or disappointed, experience a sense of injustice or existential angst, political humor is a way to get a small victory, to let off steam. The essence of political humor has always been how people wrestle with the human condition, how those who feel victimized or discriminated against negotiate humiliation.

Satire knows few boundaries. It is present in all kinds of organizations and societies. Political satire can be, in part, a response to moral frailty, a defense against the misdeeds or inadequacies of those who try to lead us.

Politicians and the act of politics fascinates people because we ask would-be leaders to help us achieve noble public purposes yet simultaneously force them to engage in sundry political wheeling and scheming to make even modest progress. Most political leaders function up on stage under the floodlights of public scrutiny. A politician's responsibilities usually call for candor and transparency, yet his or her political survival regularly demands discretion, cunning, and vagueness. In any event, when they fail, falter, or dash our invariably high expectations, we are disappointed, and sometimes angry. One recourse is to laugh at them.

Freud, in his treatise The Joke and its Relation to the Unconscious (1905 [1960]), suggested that jokes can be a rebellion against authority, a therapeutic way of coping with a lack of power. Making fun of those in power, he added, serves to deprive them of their claim to dignity and authority. Ironic and dark disparagement has often been one of the few weapons available for the oppressed.

Other reasons encourage us to laugh at our leaders. Here are just a few:

- to relieve despair (worry about economic woes, political polarization, etc.)

- to vent our resentment at the unfairness of things (poverty, inequality, perverse regulations)

- to flout authority, express our independence from government or elites

- to escape the intensity of vituperative rhetoric and negative campaigning, or just be entertained (sit back, not get involved)

- to feel part of an in-group (such as audiences for Jon Stewart, Stephen Colbert, or Armando Iannucci).

Jonathan Swift's infamous A Modest Proposal (for Preventing the Children of Poor People from Being a Burden to their Parents or Country, and for Making Them Beneficial to the Public) (1729 [2009]) is perhaps the godfather of modern western political satire. In an effort to shame the ruling British elite in Ireland, rally the downtrodden Irish Catholic poor, and mock do-gooders' ineffective schemes, Swift satirically proposed that poor Irish 1-year-olds be used as food to solve mutual problems. Swift published his pamphlet anonymously (for obvious reasons). It remains one of the most biting examples of political satire ever devised.

Political humor has multiple functions: (1) questioning the uses and abuses of power; (2) mocking hypocrisy; (3) deriding politicians and ideologies we dislike; (4) lampooning the personal inadequacies or gaffes of political leaders; and (5) exposing injustices, and corruption. Satirists living under repressive regimes say humor is often the most salient way to highlight a country's toxic political practices.

Political satire is sometimes a source of education. It can inform us or give us a new perspective on politics. Yet political humor often reinforces our prejudices, fears, or stereotypes. Political humor can be about punishing opponents - one person's hilarious caricature may be another person's malicious hatchet job. The challenging question is whether, and to what extent, humor educates us, as opposed to making us cynical. 
Humor helps us cope with the painful and the forbidden, and thus, at least at times, helps us cope in an unfair world. We laugh at the comic incongruities of life. In part, we use jokes to highlight life's absurdities. Two British analysts suggest we tell jokes because human existence can be so unforgiving. Jimmy Carr and Lucy Greeves, in Only Joking: What's So Funny About Making Us Laugh? (2006), write that political jokes are, in part, an expression of the 'alienated outsider that lives in all of us' (p. xv). They add that wherever humans 'are oppressed - by corrupt government, poverty or merely the specter of disease and death - jokes thrive' (ibid., p. 8). ${ }^{2}$

Organizational behavior scholar Manfred F.R. Kets deVries contends that humor allows us to chide hubris and covertly deal with taboo subjects. Shared laughter, he writes, contributes to group cohesion and can often reduce the distance between leader and led. 'Humor provides a gentle way of dealing with conflicts, preventing the sudden explosion of tension. It can be a formidable weapon against those who, in other circumstances, would refuse to recognize or accept truth' (Kets deVries 2003, p. 64).

Many people in today's democracies are suspicious, or at best ambivalent about their political leaders. We know someone has to solve public problems, forge policy compromises, and help govern our communities and nation-states. So we agree to transfer authority, even if reluctantly, to those who govern. We also know that a certain amount of craftiness, cunning, and even ruthlessness is often necessary in politics.

But we also fear the abuse of power, think politics unsavory, and view politicians as unprincipled. From Machiavelli to Orwell, writers warn us about the guile, coercion, and 'double-sidedness' inherent in the art of political leadership. Even at its best, goes an old truism, politics is the skilled use of a blunt instrument.

One of the ways we deal with this deep-seated unease is by laughing. Americans have a habit of remembering with relish the dumb things their politicians say. These gaffes and misstatements are, in fact, what is most often remembered about their recent political leaders. President Richard Nixon's statements 'I'm not a crook,' and, in his later years, 'When a president does it, that means it's not illegal,' set him up for merciless satire. President Bill Clinton's extra-marital affairs, and his testimony in the Monica Lewinsky case, not only provided powerful ammunition for his political opponents, but became the butt of countless ribald late-night television jokes.

President George W. Bush's premature celebration of America's 'mission accomplished' in Iraq made him look naive and feckless. Senator John Kerry's statement that he voted both for and against appropriations for the first Iraq War helped implode his 2004 campaign for the White House. In the 2008 presidential campaign, Governor Sarah Palin's comments about being able to see Russia from her home in Alaska made her an immediate satirical target and served to emphasize her lack of qualification for the job of Vice-President.

Many politicians may be dedicated and honest citizens who sincerely care about serving their constituents and solving the country's problems. But in the process of 'coming out' as political candidates, they have to promote themselves, and often find themselves making unrealistic promises; witness President George H.W. Bush's dare: 'Read my lips - no new taxes,' or candidate Barack Obama's 2008 promise of a new way of doing politics in Washington. 'If we got one-tenth of what was promised to us in these acceptance speeches,' quipped American humorist Will Rogers, 'there wouldn't be any inducement to go heaven.'

When promises are broken, a politician's 'flip-flops' become a magnet for comedic amplification. Comics mock political candidates as phony and hopelessly fixated on

2. See also Holt (2008). 
winning and retaining office. Even if there are occasional policy successes, a political leader can count on his or her constituents asking, 'what have you done for me lately?'

The experienced politician knows that he or she is a walking target for satire. Comedians and cartoonists operate as a 'disloyal opposition', a kind of third party maintaining a negative campaign long after the election is over. The official opposition party usually grants at least a short honeymoon period so it doesn't risk being labeled as a sore loser. But comics face no such obstacles. Comedians are ready to roast even the most freshly minted public servants. And politicians learn to swallow ridicule. Thus the politician's prayer: 'O Lord, give us the wisdom to utter gentle and tender words ... for tomorrow we may have to eat them.'

Laughing at political leaders can also be a way of seeking retribution, of getting back at sleaze. Political corruption is hard to remove. It is often hidden, difficult to prove. The means to punish the corrupt, such as indictment, conviction, impeachment, or recall (allowed in some places), are unwieldy and time-consuming. 'Voting the scoundrels out' in the next election is also delayed and uncertain gratification. But humor is fast and inexpensive, and can be devastatingly effective. Laughing allows us to feel we are in some way allaying the damage they have done - or may still do.

\section{HOW WE LAUGH AT LEADERS}

We have countless ways to laugh at politics and political leaders - one-liners by standup comics, cartoons and caricatures, satirical verse, satirical novels and films, snarky newspaper columns, and television punditry. Most political comedy, at least in the US, is relatively tame and consists of jokes about the game of politics and about the 'foot in mouth' syndrome of public officials. Humorists know they have to read their audiences in order to be effective. But political satire can also be a searing disparagement and malicious setting for false innuendo and name-calling. There are times when it is not so funny.

\subsection{One-liners from stand-up comics}

American comedian Bob Hope was once honored at a Washington, DC Kennedy Center ceremony, and joked, 'There are so many Congressmen and Senators here that I don't know whether to tell a joke or pass a bill.' He paused briefly, then added, 'As if there is a difference. ${ }^{3}$ Stand-up comics in every country (at least those permitting free expression) make us laugh at the absurdity, the hypocrisies, and the foibles of everyday political life. Their collective motto is: 'leave no politician unroasted.'

American wit Will Rogers gratefully joked that it's pretty easy being a humorist when you have 'the whole government working for you.' About his own Congressman he joked, 'I'm torn between local pride and fear for the nation.' In a similar vein, Texas humorist Molly Ivins once wrote that 'if a certain congressman's IQ dropped any further, he'd have to be watered twice a day. ${ }^{4}$

Some political jokes are universal, poking fun at the game of politics, such as: 'Give politicians a free hand and they'll likely put it in your pocket,' or 'Politics is the cunning

3. Quoted in Rothstein (2010).

4. Two of Ivins's many books of this kind of humor are Ivins 1999 and 2005. 
art of getting votes from the poor and campaign funds from the rich, by promising to protect each from the other.' Here are typical one-liners about political life:

- Washington, DC is a city where many a politician is waiting to be discovered, and an equal number are afraid they might be.

- There's nothing wrong with this country that a good politician can't exaggerate.

- The louder he talked of his honor, the faster we counted our spoons.

- (Political consultant's advice to political clients:) A closed mouth gathers no feet.

- The political dinner was an array of cold mashed potatoes, withered peas, wrinkled olives, stringy celery, and rubber chicken, completely surrounded by stale speeches and moldy jokes.

- Politicians are animals who sit on a fence and try to keep both ears to the ground.

- In some African countries a man can't hold public office until he has shot a rhinoceros. In the US a person is qualified only if he can shoot the bull.

- The gifted politician is the one who can give the type of answer that makes you completely forget the question.

- A skilled politician is one who can stand up and rock the boat and then make you believe he is the only one who can save you from the storm.

- She raised vacillation to the level of moral principle.

- He was a man of his last word.

- A political war is one in which everyone shoots from the lip.

- A political campaign is often a combination (to paraphrase Churchill) of mud, threats, and smears.

- No party can fool all the people all the time... that's why we have two of them.

- Not much of a choice this year - one candidate looks like the seller of used cars, the other one looks like a buyer of used cars.

- We'll double-cross that bridge when we come to it. ${ }^{5}$

Perhaps it is true that freedom encourages jokes, and jokes encourage freedom. Every joke, claimed George Orwell, 'is a tiny revolution,' implying that whatever diminishes the dignity of those in power can be liberating. But Orwell added a darker assessment of the game of politics: 'All issues are political issues, and politics itself is a mass of lies, evasions, folly, hatred and schizophrenia.' ${ }^{6}$

Scholar and journalist Alexander Rose, however, is skeptical. In an analysis of jokes in authoritarian regimes such as Nazi Germany and the Soviet Union, Rose contends that jokes there were rarely tiny revolutions. They were merely 'temporary pain relievers serving as a substitute for being allowed to participate in real politics' (Rose 2001/2002, p. 8).

Still, political humor thrives in repressed societies in part because people who tell jokes or laugh at them create 'democracy for a brief moment' as they mimic or debunk the authoritarian ruler or regime. 'Communism,' writes Ben Lewis (2006a), 'was a humour-producing machine.' Anti-authority zingers breed in every culture, yet political jokes in communist systems grew into an anonymous yet enduring body of folk literature. 'The communist joke was by nature dead-pan and absurdist - because it

5. Many of these one-liners are merely handed down over time. There are numerous collections of political wit, including Henning (1996); Lundberg (1968); Udall (1988); and Wilde (1984). See also the reflective analysis and stories in Yarwood (2004). For an anthology of American humorists, see Baker (1993).

6. Quoted in Lundberg (1968, p. 141). See also Orwell (1984). 
was born of an absurd system which created a yawning gap between everyday experience and propaganda' (ibid.). Lewis adds, 'Communist jokes were a way to criticise and outmanoeuvre the system, but they were also something more than this. They comprised a secret language between citizens - membership of a club to which the government was not invited (or so they thought)' (ibid.). Sadly, tens of thousands were imprisoned for dissident satire.

UCLA scholar Leonard Freedman discusses regimes such as Eastern Europe and the Soviet Union that routinely censored their dissenters and satirists. Nobel Prize winners Vaclav Havel of Czechoslovakia and Wole Soyinka of Nigeria were jailed. Comedians in several countries have been beaten, jailed, or exiled. Disturb the peace, and you risk being treated like Socrates, Solzhenitsyn, Havel, Soyinka, Pete Seeger, and Dick Gregory.

Repressive nations encouraged extensively whispered humor. Freedman (2009, p. 119) shares these:

- There were Brezhnev jokes. President Carter asked Brezhnev whether he collected jokes against himself. 'I certainly do.' 'How many?' asks Carter. 'Two camps full,' says Brezhnev.

- Some of the jokes and variations of them were told in eastern European countries that were under Soviet domination from 1945 to 1991. One favorite, relating to the regimes of the Soviet and East European leaders, announced a competition for the best political joke. The first prize: 15 years.

\subsection{Cartoons and caricatures}

A well-crafted cartoon sometimes proves a more subversive weapon than a rival's best political argument. 'Stop them damn pictures,' said New York City's legendary 'Boss', William Marcy Tweed, about Thomas Nast's mocking cartoons. 'I don't care what the papers write about me - my constituents can't read. But damn it, they can see the pictures. ${ }^{7}$

It is hard to rebut or answer a political cartoon or caricature. By definition, cartoons distort and exaggerate. But those on the receiving end cannot easily complain about the cartoons misrepresenting them because cartoons are supposed to exaggerate. Cartoons or caricatures can make a hard-hitting point, yet hide behind their inherent silliness when they come under fire. If you dislike an editorial you can write a letter to the editor, yet it's much harder to send a counter-cartoon to the editor.

Occasionally cartoonists pay a price. Honore Daumier, a noted nineteenth-century French cartoonist, was arrested and jailed for a caricature of King Louis Phillipe. Contemporary cartoonists elsewhere have been jailed, threatened, fired, or censored.

A few years ago, we witnessed an international cartoon 'war' between Danes and Iranians. Muslim outrage was triggered over comedic caricatures of the prophet Mohammed in a Danish newspaper. In retaliation, an exhibition of cartoons belittling the Holocaust went on display in Tehran.

Sculpture can also be used to send satirical messages to political elites. In 2013, just before the Czech Republic's national elections, sculptor David Cerny created a 30-foothigh purple plastic hand with a decidedly raised middle finger. The subversive and to many politically frustrated Czechs - welcome gesture was a 'scream of alarm' floating in the Vltava River aimed at the Prague Castle. Cerny left little doubt about his disgust

7. 'Boss' Tweed, quoted in Lordan (2006, p. 33). See also Navasky (2011, p. SR5) and Deans Halloran (2013). 
with the current regime and the belief that the 1989 revolution there had failed to keep its promises. $^{8}$

\subsection{Satirical verse}

When the Democratic candidate Grover Cleveland (who had fathered a child out of wedlock) ran for the US Presidency, Republicans jeered with this chant: 'Ma, Ma, where's my Pa?/ Gone to the White House/ Ha, ha, ha!' In a more recent example of satirical verse, political scientist Leonard Freedman, in The Offensive Art: Political Satire and its Censorship Around the World (2009, pp. 1, 11), shares this doggerel:

The President's role has impressively grown

Until it's attained an imperial tone.

But that makes a target that's bound to enthrall

Conrad, Art Buchwald, Jon Stewart and all

(and, in similar verse)

Political satire to be most effective

Is caustic, unfair, and never objective.

With all this in mind, you may ask why I'm for it.

The answer is simple: Tyrants abhor it. ${ }^{9}$

The American novelist and humorist Calvin Trillin (2012) has this sarcastic verse about libertarian novelist Ayn Rand:

(to be sung to the tune of 'Blue Moon')

Ayn Rand,

Because of you I'm now free

Because of what you have taught

I know it's all about me.

Ayn Rand,

You taught we should be ambitious,

And strive to be avaricious,

Since money's truly delicious.

And we shouldn't share a nickel of this money

With citizens who can't prevail.

The government is not the Easter bunny.

The poor are weaklings who deserved to fail.

Ayn Rand

Before you, I was immobile.

Because of you I now know

That being selfish is noble.

\subsection{Satirical novels and films}

Novelists and film-makers in every culture have lampooned political leaders. Sometimes this is in the form of irony, sarcasm, or parody. Sometimes the work disparages

8. Bilefsky (2013).

9. See also Tartakovsky (2008, p. A13). 
the political ethos of the day, sometimes specific political leaders. Novels and films may entertain, but they may also be covert acts of resistance.

In their novel The Gilded Age (1873 [1969]), Mark Twain and Charles Dudley Warner portray post-Civil War America as overrun with sleazy promoters and self-serving pretentious politicians. They provide caricatures of politicians, mockery, and trenchant rebukes of the governing practices of that era. Twain had been a participant observer as a reporter and short-term aide to a couple of office holders. This, Twain's first novel, was written to expose hypocrisy, to enlighten the public and to encourage political reform.

Taking oneself too seriously is an occupational hazard in every profession, yet especially so in politics. American historian and novelist Henry Adams, in his Democracy: An American Novel (1880 [1968]), portrays a fictional president constantly making a fool of himself. And Adams's chief protagonist, a prominent US Senator, confesses, 'I am a politician because I cannot help myself ... In politics, we cannot keep our hands clean' (ibid., p. 158).

Mexican novelist Carlos Fuentes, in his book The Eagle's Throne (2006), has a central character advise a younger politico that 'to be a politician you must be a hypocrite.' Most of his other politicians are cleverly depicted as calculating dissemblers, fixers, and opportunists.

Contemporary novelist and social commentator Christopher Buckley is a raucously funny political satirist. He lampoons the US Senate and its pretentious confirmation hearings process in the comic novel Supreme Courtship (2008). The book is an entertaining read, but it has a serious side underneath the humor. Buckley skewers pompous and selfrighteous officials, and exposes dysfunctional aspects of the American presidentialcongressional separation-of-powers system.

Film-maker Stanley Kubrick directed a number of Hollywood movies that made his audiences both laugh and cry at toxic political leadership. His classic, Dr. Strangelove, or How I Learned to Stop Worrying and Love the Bomb (1964) is a chilling burlesque of how Cold War commanders and strategists came up with the idea of 'Mutual Assured Destruction' - the notion that the US and the USSR would refrain from all-out nuclear war because the other side could destroy them. The film depicts American political leaders as naive, ineffectual, short-sighted, and dangerously prone to aggressive posturing. The name Dr. Strangelove became part of the political lexicon, used to refer to an unnatural and strange infatuation with the destructive power of nuclear weapons. While the movie caricatures are screamingly funny, Kubrick leaves his viewers with diminished trust in political and military elites. He offers no heroes, but implicitly calls for a major re-examination of the culture that encourages societal marches to folly. ${ }^{10}$

Scottish comedy writer Armando Iannucci is another caustic political satirist. His 2009 film In the Loop ridicules a thinly disguised Prime Minister Tony Blair, along with Blair's political advisers, for their decision to go to war in Iraq. If Alan Sorkin's television series West Wing provided viewers with a generally benign portrait of a hard-working chief executive with his band of advisers, Iannucci, by contrast, paints a relentlessly unflattering picture of a prime minister and his inner circle. Political leaders in the film are depicted as bone-headed, obstinate, prone to bluster and foul language, competitive, and incapable of working together. While viewers may laugh at the exaggerated portraits of politicians, the not-so-subtle message is that Britain's political leadership was duplicitous or worse.

10. Two seminal books that elaborate on the themes in Dr. Strangelove are Tuchman (1984) and Lipman-Blumen (2005). 


\subsection{Snarky newspaper columnists}

Noted US newspaper columnist H.L. (Henry Louis) Mencken made a career badmouthing politics, politicians, and electioneering. He loved to exaggerate, and traded in ruthless invective. Mencken separated the political elite into those with and those without character. Politicians, he found, were mostly without character. He quipped, 'A good politician is quite as unthinkable as an honest burglar.' The characterchallenged public officials are timid, cautious, and base, 'all the immemorial qualities of a politician.'

'Politics, under a democracy,' Mencken held, 'reduces itself to a mere struggle for office by flatterers of the proletariat; even when a superior man prevails at this disgusting game, he must prevail at the cost of self-respect.'

Mencken's was the humor of a demolition specialist, targeting those who, in Disraeli's phrase, 'climb to the top of the greasy pole' of politics. Mencken was consistently irreverent, elitist and mostly cynical in smiting the 'reigning clowns.' 'Every decent man,' he wrote, 'is ashamed of the government he lives under.'

One choice Mencken snipe was his description of US President Warren Harding, who 'it must always be added, ... has the courage of his hypocrisies. ${ }^{\text {'1 }}$

Among America's gifted and consequential satirists is New York Times columnist Maureen Dowd. A Pulitzer Prize winner, and exceptionally well-read, she has an uncanny grasp of US politics. Dowd's abrasive and sassy ridicule equals in sheer nerve most of her subjects' craving for self-promotion. 'She uses all the traditional tools of comedy,' writes movie critic David Denby (2009, p. 109), 'exaggeration, lampoon, insult, outrageous puns, fantasia - and gives them her own twist.'

Dowd is effective at deriding self-righteous politicians, especially those who fail to live up to their campaign promises, or who shy away from courageous or constitutional positions. Her chatty conversational style and rapier wit mask how biting her criticisms can be. An equal-opportunity lampooner, 'she tugs at everyone who climbs into the saddle and, sooner or later, pulls them off the horse' (ibid.). George W. Bush, Cheney, the Clintons, Barack Obama, and virtually every recent US presidential candidate have felt her incisive sting. One suspects that Washington, Jefferson, Lincoln, and FDR, Churchill, and de Gaulle, would also have had their reputations deflated, if not shredded, if Dowd had put them on her 'couch.'

Dowd's subjects typically appear to be motivated by pride, narcissism, or selfaggrandizement. With disturbing regularity, she discovers folly, bone-headedness, or cowardice. Critics say she views her subjects through an overly misanthropic prism. Her caricatures can be so palpable and so intense that they leave the reader with a malodorous view about the life of politics.

'For her,' writes Denby (ibid.), 'politics is a stupid, despair-inducing entertainment ...' He worries that Dowd's columns too often focus on personality, attitude, and style, rather than on policy ideas or principles. 'She never seems to wonder what an ambitious leader might do besides gratify himself,' he complains.

Here is vintage Dowd (2013a, p. 13) on President Obama. She praises Obama for learning how to connect emotionally with the American people in searing moments when he follows (to paraphrase the poet Yeats) 'the blood-dimmed tide drowning the ceremony of innocence,' yet she adds, 'Unfortunately, he [Obama] still has not learned how to govern.'

11. See Mencken (1960; 1980); and various websites for lists of Mencken quotes and aphorisms. 
Obama may be, in Dowd's (2013b, p. 23) words, 'our sophisticated, sleek, smart and detached president,' but he and his drone policy have been seduced by 'our sophisticated, sleek, smart, detached war machine.' Ultimately, she admonishes, 'it is a drain on the democratic soul to zap people with no due process.'

Denby asks too much of Dowd when he laments her watchdog (attack dog) approach. She does recommend useful policy initiatives from time to time. Moreover, it's okay just to be a political satirist. Political humorists need not also be political philosophers or policy wonks. But Denby raises a valid - and important - point when he suggests that snarky political satire, such as Mencken's or Dowd's, reinforces our view of politics as a sour, toxic, and near-hopeless enterprise.

\subsection{Snarky television punditry}

British political humor is more choleric and more condescending than most American political humor. British political comedy often comes so close to humiliation, writes James Wolcott (2013, p. 30), 'that it pops out the other side, liberated from any illusion about civility, decency and fair play.'

Prize-winning British broadcaster Jeremy Paxman is known for his brusque, abrasive interviews with British politicians. Fans call him incisive and rigorous; critics see him as rude, arrogant, and unfair.

Paxman considers himself an aggressive, non-aligned, independent, 'bullshitdetecting' journalist searching for news and truth. His suspicion, if not contempt, for the motivations and practices of politicians is bluntly put in The Political Animal: An Anatomy (2003):

In much of the popular mind, politicians are all the same. They're a bunch of egotistical, lying narcissists who sold their souls long ago and would auction their children tomorrow if they thought it would advance their career. They are selfish, manipulative, scheming, venal ... and if you shake hands with them you ought to count your fingers afterwards. They are not people you would want your son or daughter to marry. ${ }^{12}$

One of America's influential political satirists is Jon Stewart, who worked both in comedy and on various television talk shows before inheriting Comedy Central's cable television show The Daily Show in 1999. Stewart's anchor desk, celebrity guests, and program format mimics that of mainstream television news shows. His show regularly captures a youngish audience, as much on its internet site as on its cable television slot. While his viewers often regard what they learn from him as real news, Stewart demurs. 'What we do is social criticism,' he says, 'it's just done through comedy.' His program is mere comedy, he suggests, and doesn't pretend to be educational or informative. ${ }^{13}$

Humor on The Daily Show and on Saturday Night Live typically involves stretching or exaggerating some real event. (The best political jokes have a grain of truth to them.) These shows give us a 'heightened reality' that can be more interesting and is certainly more entertaining - than the original event. Their approach may increase our interest in politics at the same time that it decreases our trust in the enterprise of politics.

12. A somewhat less rapacious analysis of politicians than Paxman's, in Washington, DC, is offered by Dana Milbank (2008). For yet another entertaining satirical 'take-down' of statusobsessed politicos and their pals, see Leibovich (2013).

13. Jon Stewart quoted in Bates (2011, p. 47). 
Stewart knows his show can be annoying. But he feels it is helping to keep politicians and media personalities accountable. He attributes his success, which is considerable, to his viewers' dissatisfaction with political leaders and mainstream news analysts.

Stewart mocks Democrat Obama as well as Republicans Bush, Romney, et al. He is rough on Fox News, and searingly sarcastic about CNBC's Jim Cramer and MSNBC's Chris Matthews. He likes to sting fellow media types when they become preachy or fail to fact-check their stories. He has been especially sarcastic on several occasions when CNN boasted of 'exclusive breaking news' that turned out to be wrong.

Stewart is modest about the role of a political satirist. At the same time as he criticizes Barack Obama for becoming a managerial rather than a transformative leader, Stewart acknowledges his own role as minor. Being a television political satirist for a half-hour four evenings a week, he says, is different from being a political leader in a complicated and intransigent world. 'I recognize my own impatience, and I understand that I am incredibly unfair,' he says. 'As someone who does what I do, it's very easy to say what I say. It's tougher when you're actually in it, like [Obama] is.' 14

Stewart defines his role as sitting back and complaining about politics. 'It can be sharp and it can be pointed and shaming, but at heart, it's impotent and sort of feckless. ${ }^{15}$ Indeed, he can venture into boorish, high-school humor, and sometimes he seems to use ['freaking'] four-letter words in a self-conscious effort to be hip. But his style is effective, especially among young viewers. He offers a potent enticement to his fans, namely the feeling that watching his show makes one part of an 'in-group' a privileged club that understands the real nature of politics, and can afford to be cynical about it.

While giddily and addictively entertaining, The Daily Show, along with The Colbert Report and Saturday Night Live, subtly build and encourage a skepticism, a cynicism, and distrust about the life of politics. Polls show that younger viewers especially tend to trust these political comedians to tell the truth more than they trust political leaders. ${ }^{16}$

Stewart's liberal ideology is pervasive. He relentlessly skewers conservative positions. And he seldom gives a positive shout-out to political leaders when they are successful. However, he went out of his way to speak in defense of Egyptian television satirist Bassem Yousef, who was briefly arrested by Egyptian authorities in 2013.

Conservatives have tried to launch satirical shows, on Fox TV and elsewhere, but these shows have failed. Perhaps conservative satirists are challenged by their own audiences, who are less tolerant of making fun of American religion, American business, and American exceptionalism. Broader audiences fault conservative satirists if they even go near humor that sounds sexist, racist, or homophobic. Conservatives and libertarians outmatch liberals on talk radio and cable television programs, but political humor seems to be harder for conservatives to pull off.

'Historically, satire has been a weapon of the underdog, and it always has been used against the dominant,' reasons political scientist Alison Dagnes (2012, p. 212). By its nature, political satire challenges power structures and confronts the establishment. Mocking those in power generally requires an oppositionist or 'outlier' mentality. 'Conservatism supports institutions, and satire aims to knock these institutions down

14. Bates (2011, p. 50).

15. Bates (2011, p. 47).

16. One study, however, reports evidence that politician visits on these comedy talk shows can encourage at least some viewer engagement with substantive policy issues. See Parkin (2010). 
a peg,' continues Dagnes (ibid., p. 212). As one American political troupe Capitol Steps boasts, 'We put the mock back in Democracy.'

\subsection{Not so funny?}

Beneath much political satire lurks the unexpressed hope for better, more enlightened political leaders, for improved political and social circumstances. There is, behind this type of political humor, a kind of latent idealism, the belief that our system can be made to work: by pointing out the flaws, we might actually be able to fix things.

But political satire can be used for less idealistic purposes. Political satire often encourages a general skepticism and distrust of public officials, a pervasive sense of government ineptitude, but it can also encourage prejudices, antagonisms, and hatreds. Humor can be used as a way to sling mud at opposition candidates, impugn their motivations and their character, and generate fear or fury. Political satire can be funny until it isn't.

Gadfly political blogger Andrew Sullivan claims people have stopped trusting our venerated institutions for a reason. 'We live in a society in which The New York Times feeds us government lies, the United States government presides over the systematic torture of prisoners, and the Vatican presides over a global conspiracy of child rape.' Sullivan adds: 'Do you really expect anyone under 30 to trust institutions anymore?'17

Cynicism and skepticism flourish in every society - and are a part of what can be called the separation of brain and state. Political satirists are only one of many contributors to diminished faith in the political process. But British political scientist Matthew Flinders warns that snarky political satire in Britain, the US, and elsewhere encourages an increasingly aggressive 'bad-faith model of politics.' What Flinders, Denby, and kindred critics worry about is that, in their relentless comedic put-downs, these ingenious satirists portray most political actors as greedy, ineffectual buffoons. ${ }^{18}$

When does political humor cease to be a laughing matter? Humor can misinform, and in its worst forms, encourage hate and mindless bigotry. Paul Lewis, in his Cracking Up: American Humor in a Time of Conflict (2006b, p. 205), warns that, like raunchy sexist jokes or mean-spirited ethnic jokes, political humor can exacerbate social problems. David Denby likens political snarkiness to hazing, or childish name-calling, akin to 'trash-talking' in sports or war-mongering demagoguery. Snark, says Denby (2009, p. 57), seizes on another person's vulnerability: 'It exploits - slyly, teasingly race and gender prejudice.'

Do we gain much from comedian Al Franken's Rush Limbaugh is a Big Fat Idiot (1996), or from US talk-radio's Rush Limbaugh wisecracking about Barack Obama's middle name or calling a young college student a 'feminazi'? Attack humor, like negative political ads, is divisive and polarizing. ${ }^{19}$ Lewis (2006, p. 205) reminds us that 'while rules regulating comic speech are absurd and self-defeating, we have much to gain by avoiding both cruelty and deception in joking.'

Critical satirical documentaries, often called 'mockumentaries,' have made us laugh at nearly every politician. But do they cross the line into character assassination? Appropriate boundaries for political satire are nearly impossible to define.

17. Quoted in Heilpern (2013, p. 60). See also Mearsheimer (2011).

18. Flinders (2012, p. 155). See also Hetherington (2005).

19. See, for example, Swint (2008). 
American left-wing populist Michael Moore's box-office hit Fahrenheit 9/11 (2004) ridiculed President George W. Bush's leadership in the aftermath of 9/11. The movie portrayed the Bush family as cozy with the Saudi Arabians, and even with the family of Osama Bin Laden. It mocked the US Patriot Act, and Bush's ineptness in the war against the Taliban. The film won Cannes Film Festival honors and earned big money, yet its unmistakable agenda was to make Bush look stupid and ineffective.

Fahrenheit 9/11 inspired the film Hillary: The Movie (2007), produced by a US group called Citizens United. Less a documentary than unabashed mud-slinging, the movie depicted presidential candidate Hillary Clinton as a congenital liar, worse than a Richard Nixon. It was temporarily banned by US federal courts as an abuse of campaign laws then in place, but then in a stunning reversal was allowed by the US Supreme Court as campaign speech.

Also inspired by Moore's Fahrenheit $9 / 11$ was a high-grossing anti-Obama film called 2016: Obama's America, produced in 2012 by conservative pundit Dinesh D'Souza. Basically outlining a conspiracy theory, the film 'otherized' Obama as insufficiently American. D'Souza and his producers pegged Obama as a radical socialist, inspired not by the American Dream, but by some ill-defined anti-colonialist rage, a dream he supposedly inherited from his African father.

'Mockumentaries' come from the right and from the left. Trafficking in innuendo and conspiracy, they encourage us to laugh at the foibles of their subjects. But they also encourage us to fear - and to hate - these subjects. To a certain extent, these 'mockumentaries' are a response to the hagiographic campaign documentaries produced by candidates for party conventions and television ads. Yet they have few redeeming virtues, and have instead become part of our 'race to the bottom.' Snark has become the handiest way, writes Denby (2009, p. 65), 'of re-packaging the anger as smear.'

Saturday Night Live's talented Tina Fey, mostly in good taste, nailed Governor Sarah Palin's vulnerabilities during the 2008 US Presidential elections. But others became objectionably sexist in their comedy routines. A number of bloggers created their own videos in 2008, some of which went viral. Candidates Sarah Palin and Hillary Clinton received a disproportionate amount of negative attention in these videos.

One study concluded that gender stereotypes and sexist objectification were rampant in both the media and the blogosphere. Candidates were faulted for being too feminine, or for being too masculine, for being too folksy or too controlled. The impression given was that political candidates could not be simultaneously feminine and competent as national political leaders. 'The portrayals of Palin were particularly harsh,' writes political scientist Todd Belt, and these videos 'portrayed her as relying completely on her charm as a candidate, utterly devoid of policy ideas.' 20

\section{DISCUSSION}

A veteran student of political humor once suggested that the most effective political humor doesn't demean politicians, political institutions, or a country. Vulgar and mean-spirited jokes, he said, usually fail. The best political humor 'has a little love behind it' (Udall 1988, p. 8). That's why American comics Will Rogers and

20. Todd L. Belt, 'Viral Videos: Reinforcing Stereotypes of Female Candidates for President,' paper loaned to the author in 2010. Belt is a Professor of Political Science at the University of Hawaii in Hilo. 
Bob Hope, and shows like Saturday Night Live, succeeded. They poked fun at politicians, yet cared for their country and the promise of constitutional democracy.

Effective political humor makes us laugh not only at politicians but at ourselves and life. Cervantes' Don Quixote and Woody Allen's films do precisely this. Stanford University scholar James March writes:

Cervantes glorifies laughter, not because comedy must serve a serious aim, such as teaching us something, but because laughter is fundamental. It allows us to go beyond our tragic condition, to understand the human condition better, recognizing that life is intrinsically funny...

Don Quixote celebrates imagination, commitment, and joy. He reminds us of how ambiguous reality is and how it can be subject to humorous interpretations. He thus makes us aware of certain absurdities in the life of a leader ... and the comic nature of the posturing and pretensions of leaders. (March and Weil 2005, pp. 90-91)

'The privilege of roasting our politicians is simply one more example of our democracy at work,' writes political humorist Larry Wilde (1984, p. 2). 'Few nations in the world allow this kind of criticism. When foreigners used to censorship settle in the United States, they are aghast to hear Americans joke about the two major political parties' (ibid.).

Politics is the lifeblood of democracy. Without politics, parties, conflict, and debate, there are few choices and little freedom. Democracy is impossible without politics, and politics is impossible without politicians. A healthy society is a place where it is safe for issues and ideas to be freely fought-out in the public square, where it is safe to be a politician, and a dissenter, a maverick, cartoonist, or satirist. Democracy requires politicians with courage, imagination, and thick skins to be ambitious and to step forward, offer ideas and choices, to listen and debate, and be willing to be criticized, just as much as they must be willing to make decisions and compromises. ${ }^{21}$ Healthy communities everywhere benefit as well from humorists with the courage and imagination to deflate pompous politicians and to help keep politicians accountable. The larger point is that politics and politicians, after all the laughing is over, are an indispensable part of governing and government.

Political humor is impossible to regulate: paradoxically, it responds to and co-exists with the fact that politics and politicians are a necessary and indeed an indispensable part of constitutional and democratic life.

It's good to laugh at politics and salute humorists. We will continue to ask of politicians the impossible. They in turn will struggle and sometimes succeed. We will form our judgments and predictably laugh at their failings. Politics is a tough, rough, ceaselessly demanding, and unsentimental profession. We force politicians to relentlessly promote themselves, place them in no-win situations, and then mock them for what we assume they could or should have done.

Humor signals to politicians that we are watching them, more carefully and irreverently than they might wish. For the mindful politician with a good ear, however, it's often a useful early warning system.

The functions of humor, as noted, include entertainment, education, protest, and insult. A well-crafted political joke can sometimes be a small act of political resistance. It is one of the ways people try to make sense of the world. Yet political humor can also be a disguise for mean-spirited rudeness and malicious mud-slinging.

21. Useful defenses of politics and political life can be found in Fairlie (1969); Crick (1962 [1972]); Riddell (2011); Gutmann and Thompson (2012); and Medvic (2012). 
Those of us who favor a spacious interpretation of free speech oppose censorship and codes against 'hate speech.' Political snark should be called out by citizens and consumers, not by governmental prohibitions. The US Supreme Court, to its credit, has gone to considerable lengths to protect freedom for both the ideas and the jokes we hate. Public officials in the US cannot sue for libel unless they can convincingly establish that false statements were uttered recklessly and knowingly. This is difficult to do. The government, the US Supreme Court ruled, may not prohibit satire, or the expression of an idea, simply because society finds it offensive or disagreeable. ${ }^{22}$

Still, the concern posed by Matthew Flinders (2012) remains. He asks (and I paraphrase): is kicking the life out of politics, politicians, and leaders really funny if at the end of the day we discourage good people from thinking seriously about civic, societal, and moral responsibilities? What happens when politics and political leaders are derided with such invective that most voters end up thinking of politics as a bad joke? Has our increasingly hip culture of snarky irony rendered sincerity and confidence in politics near impossible?

Political comedy can understandably be edgy, and is by definition subversive or even transgressive. That said, we need also to appreciate that corrosive antipathy to politics and governance makes it harder for societies to address crucial policy priorities such as social justice, sustainability, and enlightened fiscal and security planning.

Politics is inevitable, necessary and desirable. We need political conciliators who try to bring us together and bring out our best abilities as we strive to achieve mutually shared aspirations. Yes, we need to laugh at politics, but we also need to encourage good people to consider the challenge of politics and honor those who are effective at it.

Demeaning politics and politicians isn't always a laughing matter. Rich political humor should leave us laughing, curious, perhaps unsettled, yet not giving up on politics.

22. See Lewis (2007). 


\section{REFERENCES}

Adams, Henry (1880 [1968]), Democracy: An American Novel, New York: Airmont.

Baker, Russell (ed.) (1993), Russell Baker's Book of American Humor, New York: W.W. Norton. Bates, Eric (2011), 'Jon Stewart: The Rolling Stone Interview,' Rolling Stone, September 29.

Bilefsky, Dan (2013), 'Artist Makes Public Criticism of Czech Politics,' The New York Times, October 22, p. A4.

Buckley, Christopher (2008), Supreme Courtship, New York: Twelve.

Carr, Jimmy and Lucy Greeves (2006), Only Joking: What's So Funny About Making People Laugh?, New York: Gotham Books.

Crick, Bernard (1962 [1972]), In Defence of Politics, Chicago: University of Chicago Press.

Dagnes, Alison (2012), A Conservative Walks into a Bar: The Politics of Political Humor, New York: Palgrave Macmillan.

Deans Halloran, Fiona (2013), Thomas Nast: The Father of Modern Cartoons, Chapel Hill, NC: University of North Carolina Press.

Denby, David (2009), Snark: It's Mean, It's Personal, and It's Ruining Our Conversation, New York: Simon and Schuster.

Dowd, Maureen (2013a), 'No Bully in the Pulpit,' The New York Times, April 21.

Dowd, Maureen (2013b), 'The CIA's Angry Birds,' The New York Times, April 17.

Fairlie, Henry (1969), The Life of Politics, New York: Basic Books.

Flinders, Matthew (2012), Defending Politics, Oxford: Oxford University Press.

Franken, Al (1996), Rush Limbaugh is a Big Fat Idiot, New York: Penguin.

Freedman, Leonard (2009), The Offensive Art: Political Satire and its Censorship Around the World from Beerbohm to Borat, Westport, CN: Praeger.

Freud, Sigmund (1905 [1960]), The Joke and its Relation to the Unconscious, New York: W.W. Norton.

Fuentes, Carlos (2006), The Eagle's Throne, New York: Random House.

Gutmann, Amy and Dennis Thompson (2012), The Spirit of Compromise: Why Governing Demands it and Campaigning Undermines it, Princeton, NJ: Princeton University Press.

Heilpern, John (2013), 'Out to Lunch with Andrew Sullivan,' Vanity Fair, May.

Henning, Chuck (ed.) (1996), The Wit and Wisdom of Politics, Golden, CO: Fulcrum.

Holt, Jim (2008): Stop Me If You've Heard This: A History and Philosophy of Jokes, New York, W.W. Norton.

Ivins, Molly (1999), Molly Ivins Can't Say That, Can She?, New York: Vintage.

Ivins, Molly (2005), Who Let the Dogs In? Incredible Political Animals I Have Known, New York: Random House.

Kets de Vries, Manfred F.R. (2003), Leaders, Fools and Imposters: Essays on the Psychology of Leadership, New York: iUniverse.

Leibovich, Mark (2013), This Town: Two Parties and a Funeral - Plus Plenty of Valet Parking in America's Gilded Capital, New York: Blue Rider Press.

Lewis, Anthony (2007), Freedom for the Thought that we Hate: A Biography of the First Amendment, New York: Basic Books.

Lewis, Ben (2006a), 'Hammer and Tickle,' Prospect Magazine, May 20, available at: www. prospectmagazine.co.uk/magazine/communist jokes.

Lewis, Paul (2006b), Cracking Up: American Humor in a Time of Conflict, Chicago: University of Chicago Press.

Lipman-Blumen, Jean (2005), The Allure of Toxic Leaders: Why we Follow Destructive Bosses and Corrupt Politicians - and How we can Survive Them, New York: Oxford University Press.

Lordan, Edward J. (2006), Politics, Ink: How America's Cartoonists Skewer Politicians, from King George III to George Dubya, Lanham, MD: Rowman and Littlefield.

Lundberg, Ferdinand (ed.) (1968), Politicians and Other Scoundrels: Observations - Mostly Disenchanted and Dyspeptic - from a Variety of Sages from Confucius to Marx (both Karl and Groucho) on Politics and Politicians, Secaucus, NJ: Lyle Stuart. 
March, James G. and Thierry Weil (2005), On Leadership, London: Blackwell.

Medvic, Stephen K. (2012), In Defense of Politicians: The Expectation Trap and its Threat to Democracy, New York: Routledge.

Mencken, H.L. (1960), On Politics, New York: Vintage Books.

Mencken, H.L. (1980), A Choice of Days, New York: Knopf.

Milbank, Dana (2008), Homo Politicians: The Strange and Scary Tribes that Run our Government, New York: Doubleday.

Navasky, Victor (2011), 'Why are Political Cartoons Incendiary?', The New York Times, November 13.

Orwell, George (1984), The Orwell Reader: Fiction, Essays, and Reportage, New York: Harcourt.

Oz, Amos (2006), How to Cure a Fanatic, Princeton, NJ: Princeton University Press.

Parkin, Michael (2010), 'Taking Late Night Comedy Seriously,' Political Research Quarterly, March, 3-15.

Paxman, Jeremy (2003), The Political Animal: An Anatomy, London: Penguin.

Riddell, Peter (2011), In Defence of Politicians (In Spite of Themselves), London: Biteback Publishing.

Rose, Alexander (2001/2002), 'When Politics is a Laughing Matter,' Policy Review, December 2001/January 2002, 8.

Rothstein, Edward (2010), 'The Comedian as Politician, and Often Vice Versa,' The New York Times, June 12, p. C1.

Swift, Jonathan (1729 [2009]), A Modest Proposal and Other Writings, London: Penguin Classics.

Swint, Kerwin (2008), Mudslingers: The Twenty-Five Dirtiest Political Campaigns of All Time, New York: Union Square Press.

Tartakovsky, Joseph (2008), 'In Praise of Political Insults,' The Wall Street Journal, July 2.

Trillin, Cavin (2012), Dogfight: The 2012 Presidential Campaign in Verse, New York: Random House.

Tuchman, Barbara W. (1984), The March of Folly: From Troy to Vietnam, New York: Ballantine Books.

Twain, Mark and Charles Dudley Warner (1873 [1969]), The Gilded Age: A Tale of Today, New York: Penguin.

Udall, Morris (1988), Too Funny to be President, New York: Henry Holt and Co.

Wilde, Larry (1984), The Official Politicians Joke Book, New York: Bantam.

Wolcott, James (2013), 'Of Thee I Sting,' Vanity Fair, January.

Yarwood, Dean L. (2004), When Congress Makes a Joke: Congressional Humor Then and Now, Lantham, MD: Rowman and Littlefield.

Zumbrunnen, John (2012), Aristophanic Comedy and the Challenges of Democratic Citizenship, Rochester: University of Rochester Press. 